\title{
ANALISIS PEMBERIAN KREDIT PADA PT. BANK PERKREDITAN RAKYAT SAMUDERA PAINAN
}

\author{
Shinta Oktavia Zalpi, Romi Susanto \\ Akademi Keuangan dan Perbankan "Pembangunan" Padang \\ shintaoktaviazalpi@gmail.com \\ romisusanto@akbpstie.ac.id
}

\begin{abstract}
The purpose of this study was to find out how the analysis of credit at PT. People's Credit Bank Ocean Painan. The research method used is a qualitative data analysis method, the type of data used is secondary data obtained from publication reports of Indonesian banks and the Painan Ocean Rural Bank 20152018 period. The results of this study indicate that the development of lending in 2015-2018 can be categorized in conditions improved, even though in 2016 the number of debtors had increased and in 2017 the number of debtors decreased but in the last year, namely 2018 the number of debtors and the number of nominal loans had increased and troubled debtors had decreased.
\end{abstract}

Keyword: Bank, credit

\section{PENDAHULUAN}

Terbesar yang dapat disebabkan oleh penyalurannya (kredit), maka dari itu pemberian kredit harus diberikan dengan cermat oleh karyawan yang paham dasar-dasar perkreditan serta dan dilaksanakan sesuai kebijakan dan aturan perkreditan.Bank merupakan lembaga keuangan yang kegiatan usahanya sebagai perantara keuangan yang menghimpun dana dari masyarakat berupa simpanan serta menyalurkan dalam bentuk kredit(Suarni \& Dkk, 2014). Bank terbagi dalam dua jenis yaitu Bank Umum dan Bank Perkreditan Rakyat (BPR). Bank umum dalam kegiatannya melakukan aktivitas usaha secara konvensional berdasarkan syariah menerima jasa dari pembayaran, dan BPR dalam melaksanakan kegiatan usahanya secara umum berdasarkan syariah tidak dapat menerima pelayanan jasa (Tabungan \& Persero, n.d.).

Dari usaha bank menghimpun dana dari masyarakat berupa simpanan serta menyalurkan kembali kepada masyrakat berupa kredit bank akan memperoleh keuntungan dari jumlah bunga yg diberikanuntuk nasabah simpanan dengan bunga yang dibebankan terhadap kredit nasabah (debitur). Bank dalam kegiatan usahanya mendapat keuntungan yang terbesar bisa diperoleh dari usaha 
penyalurannya (kredit), begitupun sebaliknya bank juga dapat memperoleh resiko kerugian

Istilah kredit berawal dari bahasa yunani ( credete) berarti kepercayaan (faith) dengan dasar ini berarti pemberian kredit merupakan pemberian kepercayaan. sebuah lembaga keuangan tidak akan memberikan kredit jika calon debitur tidak bisa dipercaya dan diyakini tidak bisa mengembalikan kredit (pinjamannya).(Kristiani,2015).

Dalam proses pemberian kredit banyak tahapan-tahapan yang harus diselesaikan oleh calon debitur terlebih dahulu, calon debitur mengajukan permohonan kredit kepada pihak bank dan juga akan dilakukan analisis seteleh menyelesaikan persyaratan administrasi.

Bank bisa melaksanakan analisis pengajuan kredit calon debitur jika syarat yang ditetapkan telah dipenuhi calon debitur yang bersangkutan. Selain itu terhadap data pendukung permohonan kredit bankpun menilai kelengkapan dan kebenaran informasi tersebut dengan mewawancarai dan mengunjungi ke tempat tinggal maupun tempat usaha calon debitur (on the spot). Hal ini penting untuk menghindari beberapa resiko yang dapat timbul dari penyaluran kredit tersebut.

Analisis tersebut bertujuan memperoleh keyakinan, kemampuan dan kemauan calon debitur untuk memenuhi kewajibannya terhadap bank dengan segera atau tepat waktu, baik pembayaran angsuran maupun bunganya sesuai dengan ketentuan dan kesepakatan dalam perjanjian yang telah ditetapkan.serta untuk menilai kualitas permintaan kredit tersebut baik itu calon debitur pengajuan kredit baru maupun permintaan tambahan kredit terhadap kredit yang sudah diberikan (debitur lama).

PT. BPR Samudera Painan adalah lembaga keuangan yang ada di pesisir selatan, dimana dalam kegiatan usahanya juga memberikan fasilitas kredit kepada masyarakat, memiliki tujuan membantu menunjang perkembangan ekonomi masyarakat di Pesisir Selatan,sebelum memberikan atau menyalurkan kredit kepada debitur (masyarakat) pihak PT. BPR Samudera Painan sebelumnya melakukan penilaian dan analisis terhadap calon debitur secara cermat dan teliti, sesuai dengan tatacara pemberian kredit yang telah ditetapkan, yang akan digunakan menjadi pedoman bagi pihak bank dalam menentukan kebijakan untuk kredit yang akan diberikan, seperti keaslian dokumen, jaminan (agunan), atau syarat-syarat lainnya yang akan digunakan sebagai bahan pertimbangan pimpinan/direksi bank dalam proses pengambilan keputusan dan sebagai alat informasi yang diperlukan untuk evaluasi kredit,PT. BPR Samudera dalam pemberian kredit kepada masyarakat juga harus memperhatikan aspek-aspek penting lainnya dalam proses pemberian kredit, seperti pentingnya informasi SID (Sistem informasi debitur) untuk mendapatkan informasi mengenai calon debitur yang sedang mengajukan pinjaman. semakin baik prosedur dan proses pemberian kredit yang dilakukan semakin berkualitas pula kredit yang disalurkan, oleh sebab itu analisis dalam pemberian kredit sangat dibutuhkan supaya kredit yang disalurkan berkualitas, dan sesuai keinginan. 
Dari penjelasan diatas penulis tertarik mengambil judul pada tugas akhir ini tentang Analisis Pemberian Kredit Pada PT. BPR Samudera Painan.

Berkaitan dengan judul diatas maka rumusan masalah pada tugas akhir ini adalah bagaimana analisis pemberian kredit pada PT. Bank Perkreditan Rakyat Samudera Painan.

\section{METODE PENELITIAN}

Dalam kegiatan penelitian ini digunakan metode pengumpulan dan analisis data sebagai berikut:

Metode Pengumpulan Data

a. Studi Lapangan ( field research)

Penelitian langsung pada objek terkait dengan meneliti hasil data yang diperoleh. Penelitian ini dapat membantu penulis dalam melengkapi data yang diperlukan, dengan kegiatan yang dilakukan mewawancarai pihakpihak yang bersangkutan atau pihak perusahaan, instansi yang terkait.

b. Studi ke Perpustakaan

Yaitu penelitian yang dilakukan di perpustakaan dengan membaca referensi penelitian terdahulu

Metode Analisis Data

Penulis menggunakan metode analisis data kualitatif sebagai metode penelitian yang menjelaskan secara deskriptif mengenai pelaksanaan kegiatan pemberian kredit pada PT. BPR Samudera Painan. pada metode ini ditinjau dari dua segi yaitu teori dan praktek, sehingga dapat diketahui perbedaan yang timbul yang menyangkut prinsip dasar konsep tersebut, dan pertanyaan akan terjawab dan bisa dijadikan patokan saat mengambil keputusan.

\section{HASIL DAN PEMBAHASAN \\ Landasan Teori}

Berdasarkan Undang-Undang perbankan (Undang-Undang RI No. 10, 1998) bank merupakan badan usaha yang menghimpun dana dari masyarakat berupa simpanan kemudian menyalurkannya kembali kepada masyarakat (debitur) dalam bentuk kredit serta bentuk-bentuk lainnya dengan tujuan meningkatkan taraf hidup rakyat banyak (afriyeni afriyeni, 2018).

Bank Perkreditan Rakyat (BPR) merupakan lembaga keuangan bank yang menghimpun dana dari masyarakat hanya dalam bentuk deposito berjangka, tabungan, dan bentuk lainnya yang dipersamakan dengan itu, serta menyalurkan kembali dana tersebut kemasyarakat berupa pinjaman kredit. Usaha BPR meliuputi usaha untuk menghimpun dan menyalurkan kembali dana tersebut dengan harapan memperoleh keuntungan, keuntungan BPR didapat dari spread effect dan pendapatan bunga, usaha-usaha yang dapat dilakukan BPR antara lain, menghimpun dana dalam bentuk simpanan berupa deposito berjangka, tabungan, dan atau bentuk lainnya yang disamakan dengan itu, memberikan kredit, menyediakan pembiayaan kepada nasabah dengan prinsip bagi hasil, menyimpan 
dananya pada Sertifikat Bank Indonesia (SBI), deposito berjangka, sertifikat deposito, dan atau tabungan pada bank lain.(Pundi, Fernos, \& Dona, 2018)

Kredit adalah penyediaan uang atau tagihan yang bisa dipersamakan dengan itu, melalui persetujuan dan kesepakatan pinjaman antara bank dengan pihak lain yang mewajibkan pihak peminjam untuk melunasi utangnya setelah jangka waktu tertentu beserta bunganya(Andriani \& Susanto, 2016)

Jenis-jenis Kredit PT. BPR Samudera Painan

1. Kredit umum

2. Kredit cicilan konsumtif

3. Kredit cicilan pegawai

4. Kredit usaha kelautan dan perikanan ( KUKP )

\section{Persyaratan Kredit}

Kredit Umum

1. Photo copy KTP 3 lembar

2. Pas photo $3 \times 43$ lembar

3. Photo copy KK

4. Rek. PLN, PDAM, atau TLP

5. Photo copy Agunan/Jaminan \#BPKB \& STNK 2 rangkap

6. SIUP/ Surat keterangan usaha

7. NPWP

8. Photo anggunan/jaminan 2 lembar

9. Photo usaha 2 lembar

Kredit Pegawai

1. Photo copy KTP 3 lembar

2. Pas photo $3 \times 4$ lembar

3. Photo copy KK

4. Slip gaji/ampra gaji

5. NPWP

6. Plafon lebih dari Rp 10.000000 menggunakan jaminan Plafon :

1. Kredit umum plafon sesuai dengan usaha dan jaminan

2. Kredit pegawai dan konsumtif plafon sesuai dengan slip gaji Bunga :

1. Bunga untuk kredit intern $=7 \%$

2. Kredit umum :

$$
\begin{aligned}
& -18 \%=1.000000-<50.000000 \\
& -16 \%=50.000000-<100.000000 \\
& -15 \%=>100.000000
\end{aligned}
$$

3. Kredit KUKP $=7 \%$

4. Kredit pegawai $=10,20 \%$

5. Kredit konsumtif $=18 \%$

Jangka waktu

1. Kredit umum : 1 tahun - 8 tahun ( biasa dipakai jangka $1-4$ tahun ) 
2. Kredit konsumtif : 1- 4 tahun

3. Kredit pegawai : 12 bulan - 180 bulan

\section{Prosedur Pemberian Kredit}

Secara umum prosedur pemberian kredit pada PT. BPR Samudera terdiri dari beberapa tahapan, secara ringkas tahapan tersebut dapat dilihat pada daftar gambar berikut ini:

\section{Gambar 3.1}

Prosedur Pemberian Kredit

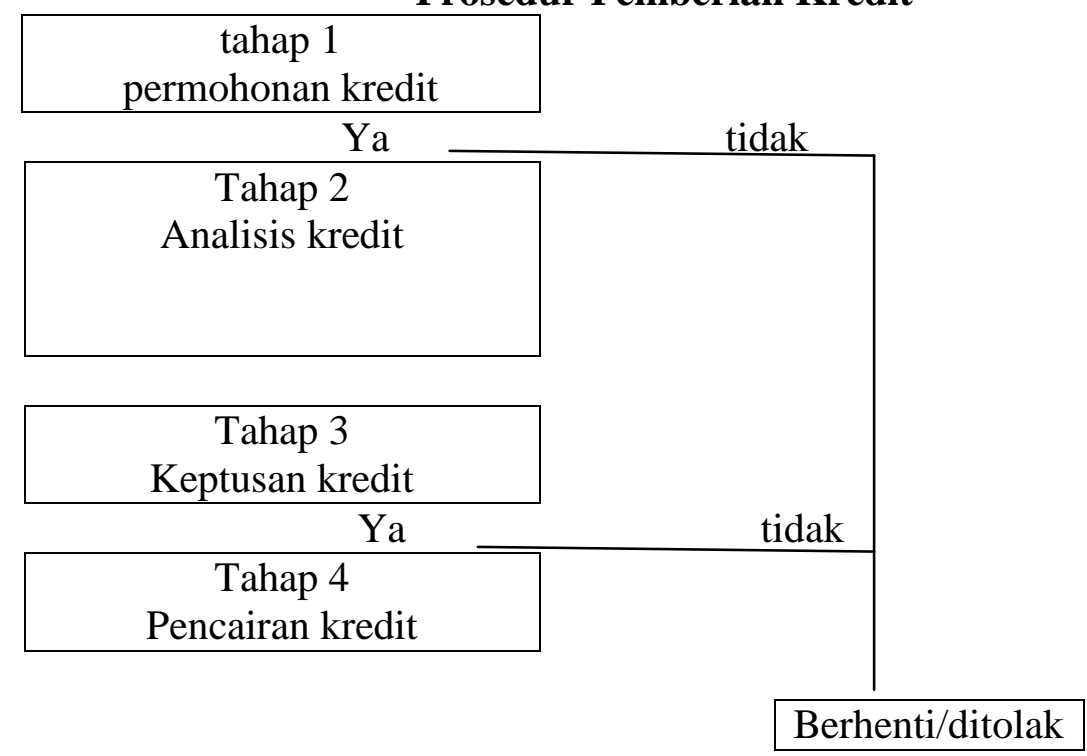

a. Tahap Permohonan Kredit

Pada tahap ini pemohon kredit harus mengisi formulir permohonan kredit serta melengkapi syarat-syarat yang telah ditetapkan pihak bank, dan menyerahkan kepada seksi pelayanan kredit.dimana persyaratan yang harus dipenuhi calon debitur sebagai berikut :

1) Identitas, berupa keterangan mengenai data pribadi/perseorangan maupuin badan usaha atau profesi calon debitur

2) Informasi tentang posisi keuangan debitur

3) Jaminan/agunan, penggunaan kredit, dan jumlah nominal kredit yang diajukan calon debitur.

4) Pada tahapan ini permoohonan kredit dapat di tolak hal ini dapat disebabkan antara lain oleh agunan yang disediakan tidak dapat menutupi jumlah pinjamannya, sebaliknya jika permohonan kredit diterima maka akan berlanjut pada tahap analisis kredit

b. Tahap analisis kredit (uji kelayakan kredit)

1) Dokumen dan formulir permohonan kredit di serahkan kepada bagian kredit (seksi lapangan) 
2) Seksi lapangan melakukan survey dan mencocokan data yang terdapat pada formulir pengajuan kredit dengan kenyataannya, dengan menyusun laporan analisa yang diperlukan yang berisi penguraian dan kesimpulan serta penyajian alternatif-alternatif sebagai bahan pertimbangan untuk pengambilan keputusan. Untuk melaksanakan analisa kredit metode 5C digunakan sebagai pertimbangan dalam pemberian kredit yaitu character (sifat), capacity (kapasitas), capital (modal), collateral (jaminan), condition of economi (kondisi ekonomi).

3) Seksi lapangan mengisi formulir evaluasi pemeriksaan kredit sesusi dengan survey yang dilakukan dan menyerahkan dokumen kepada kabaq kredit

4) Kabaq kredit mengecek dan mengevaluasi dokumen-dokumen dan kemudian menolak permohonan kredit atau melanjutkan dengan mengotorisasi permohonan kredit sebagai persetujuan awal. Kemudian dokumen tersebut di serahkan kepada direktur untuk di putuskan .

c. Tahap keputusan kredit

1) Dokumen yang telah disetujui oleh kabaq kredit diserahkan kepada direktur untuk diputuskan apakah disetujui atau di berhentikan (ditolak).

2) Jika disetujui dokumen tersebut akandi otorisasi oleh direktur

3) Dokumen yang telah di otorisasi oleh direktur dibuatkan akta perjanjian antara pihak bank dengan pemohon kredit dihadan notaris dengan ketentuan yang telah disetujui oleh kedua belah pihak

4) Jika kredit dengan jaminan, maka jaminan tersebut harus diasuransikan

5) Bagi pemohon kredit yang tidak mempenyuai rekening pada bank tersebut diharuskan membuka rekening terlebih dahulu (realisasi kredit)

6) Pihak debitur dan pihak bank menandatangani perjanjian kredit serta menyerahkan agunan yang telah dijaminkan

d. Tahap pencairan kredit

1) Apabila nasabah setuju dengan keputusan yang diambil bank maka pinjaman yang diajukan akan dicairkan

2) Slip penarikan sebesar jumlah kredit yang telah disetujui di serahkan kepada kabaq kredit untuk diotorisasi, selanjutnya diserahkan kepada sub bagian dana dan operasional dan pelaporan kas untuk diotorisasi direksi

3) Berkas pencairan yang terdapat pada dokumen-dokumen diantaranya yaitu : jumlah yag diterima nasabah setelah 
dikurangi biaya-biaya seperti biaya provisi, administrasi dan biaya premi asuransi serta biaya pengikatan aguanan.

4) Setelah dokumen-dokumen tersebut di setujui dan telah ditandatangani diserahkan ke bagian pembukuan kemudian dibuatkan kartu pinjaman dan kartu angsuran pinjamannya.

5) Berdasarkan dokumen yang masuk ke bagian pembukuan kabaq membuat tanda terima bahwa nasabah telah menyerahkan agunan dan juga membuat bukti pengeluaran umum dan kemudian diserahkan kepada teller untuk dicairkan

6) Semua dokumen diserahkan kembali sebagai arsip dan uang diserahkan kepada nasabah beserta bukti penerimaan pinjaman.

Dalam kegiatan pemberian kredit yang dilakukan oleh PT. BPR Samudera Painan tentunya mempunyai tujuan agar kredit yang disalurkan kepada nasabah dapat diterima kembali sesuai dengan waktu yang telah disepakati.Dalam hal ini keberhasilan pemberian kredit yang dilakukan dapat dilihat dengan tingkat perkembangan kredit yang diperoleh. Berikut ini adalah data yang menunjukkan perkembangan kredit yang terjadi :

Tabel 1

Jumlah debitur dan kredit bermasalah pada PT. BPR Samudera Painan Tahun 2015-2018

\begin{tabular}{|c|c|c|c|c|}
\hline Indikator & 2015 & 2016 & 2017 & 2018 \\
\hline Debitur & 461 & 484 & 483 & 512 \\
\hline Nominal Kredit & 7.037318811 & $\mathbf{9 . 9 7 7 3 5 3 5 6 9}$ & 10.258867444 & 15.266514142 \\
\hline $\begin{array}{c}\text { Debitur } \\
\text { Bermasalah }\end{array}$ & 15 & 25 & 19 & 15 \\
\hline
\end{tabular}

Sumber : PT. BPR Samudera Painan

Berdasarkan data diatas dapat dijelaskan bahwa analisis pemberian kredit yang dilakukan oleh manajemen PT. BPR Samudera Painan swbagai berikut:

Jumlah debitur pada tahun 2015 berjumlah 461 orang, meningkat pada tahun 2016 menjadi 483 orang, mengalami penurunan pada tahun 2017 menjadi 483 orang dan meningkat kembali pada tahun 2018 menjadi 512 orang.

Jumlah debitur bermasalah pada tahun 2015 sebanyak 15 orang, meningkat pada tahun 2016 menjadi 25 orang, menurun pada tahun 2017 menjadi 19 orang dan pada tahun 2018 juga menurun menjadi 15 orang. Pihak PT. BPR Samudera Painan melakukan penanganan terhadap debitur bermasalah dengan memberikan surat peringatan (SP) kepada debitur tersebut, 
surat peringatan diberikan hingga 3 kali dengan perbedaan waktu pemberian 2 smapai 3 bulan.

Jumlah nominal kredit pada tahun $2015 \mathrm{Rp} 7.037318811$ meningkat pada tahun 2016 sebanyak Rp 9.977353569, meningkat pada tahun 2017 sebanyak Rp 10.258867444 dan pada tahun 2018 juga mengalami peningkatan sebanyak Rp 15.266514142.

Dari penjelasan diatas dapat diketahui bahwa analisis pemberian kredit pada PT. BPR Samudera Painan dapat dikategorikan baik meskipun pada tahun 2016 jumlah debitur bermasalah meningkat, dan pada tahun 2017 jumlah debitur menurun tetapi pada tahun terakhir yaitu tahun 2018 jumlah debitur, jumlah nominal kredit sudah meningkat dan debitur bermasalah sudah mengalami penurunan. Dengan adanya peningkatan jumlah debitur dan jumlah nominal kredit serta dengan penurunan jumlah debitur bermasalah tersebut berarti pemberian (penyaluran) kredit yang dilakukan PT. BPR Samudera Painan sudah dalam keadaan baik dan sudah sesuai dengan tujuan penyaluran kredit yang diharapkan.

\section{SIMPULAN}

Berdasarkan analisis pada bab sebelumnya, pemberian atau penyaluran kredit pada PT. Bank Perkreditan Rakyat Samudera Painan dapat disimpulkan bahwa:

1. Prosedur pemberian kredit pada PT. Bank Perkreditan Rakyat Samudera Painan terdiri dari empat tahapan yaitu tahap permohonan kredit, tahap analisis kredit, tahap keputusan kredit dan tahap pencairan kredit.

2. Perkembangan pemberian kredit PT. Bank Perkreditan Rakyat Samudera Painan pada tahun 2015-2018 dapat dikategorikan dalam keadaan membaik, meskipun pada tahun 2016 jumlah debitur bermasalah meningkat dan pada tahun 2017 jumlah debitur menurun tetapi pada tahun terakhir yaitu tahun 2018 jumlah debitur dan jumlah nominal kredir telah mengalami peningkatan serta debitur bermasalah telah mengalami penurunan.

3. Berdasarkan analisis pemberian kredit. PT. Bank Perkreditan Rakyat Samudera telah memenuhi peraturan Surat Edaran Bank Indonesia NO. 14/26/DKBU Tentang Pedoman Kebijakan dan Prosedur Perkreditan bagi Bank Perkreditan Rakyat.

\section{UCAPAN TERIMA KASIH}

Terimakasih penulis sampaikan kepada :

1. Kedua Orang Tua yang senantiasa memberikan dukungan baik secara moril maupun materil.

2. Direktur AKBP beserta prodi AKBP yang telah memberikan kesempatan kepada penulis untuk melakukan penelitian ini.

3. Dosen Pembimbing tugas akhir yang telah memberikan arahan dan bimbingan hingga tugas akhir ini bisa terselesaikan. 
4. Pimpinan PT. BPR Samudera Painan yang telah mengizinkan penulis dalam memperoleh informasi beserta pengambilan data.

5. Semua Pihak yang telah memberikan dukungan dan bantuannya dalam penyelesaian tugas akhir ini.

\section{DAFTAR PUSTAKA}

Afriyeni A. (2018). Analisis Faktor-Faktor Penentu Kinerja Profitabilitas Bank Perkreditan Rakyat (BPR) Konvensional Di Sumatera Barat, 3(September), 325-335.

Alanshari, F., \& Marlius, D. (2018). Prosedur Pemberian Kredit KPR Pada PT. Bank Tabungan Negara (Persero) TBK Cabang Pembantu Bukittinggi. https://doi.org/10.31227/osf.io/rsfhc

Amelia, L., \& Marlius, D. (2018). Pengendalian Kredit Dalam Upaya Menciptakan Bank Yang Sehat Pada PT. Bank Pembangunan Daerah Sumatera Barat Cabang Utama Padang. https://doi.org/10.31227/osf.io/kpc64

Andriani, B., \& Susanto, R. (2016). Pengawasan Kredit PT. Bank Perkreditan Rakyat (BPR) Ophir Pasaman Barat. Akademi Keuangan Dan Perbankan, 1-12.

Barus, A. C., \& Lu, M. (2013). Pengaruh Spread Tingkat Suku Bunga Dan Rasio Pada Bank Umum Di Indonesia. Jurnal Wira Ekonomi Mikroskil, 3(April), 1120. https://doi.org/10.1017/CBO9781107415324.004

Budiasih, Y. (2012). Struktur Organisasi, Desain Kerja, Budaya Organisasi dan Pengaruhnya Terhadap Produktivitas Karyawan. Jurnal Liquidity, 1(2), 99-105.

Darussalam, O. (2013). Faktor-Faktor Penyebab Kredit Bermasalah di PT.Bank Sulut Cabang Utama Manado. Jurnal EMBA, 1(4), 69-77.

Darmawanto, \& Fernos, J. (2019). Prosedur Pemberian Kredit Pada Bank Nagari Cabang Sijunjung. https://doi.org/10.31227/osf.io/psqfy

Fernos, J., \& Dona, E. (2018). Analisis Loan To Deposit Ratio , Capital Adequacy Ratio dan Return On Assets PT . Bank Pembangunan Daerah Sumatera Barat, 02(02), 107-118.

Ikbal, M., \& Marlius, D. (2017). Pengaruh Jumlah Taksiran Dan Uang Pinjaman Terhadap Laba Bersih Pada PT. Pegadaian (UPC) Gurun Laweh. https://doi.org/10.31227/osf.io/uch4a

Kristiani, L. E., Akuntansi, P. S., Ekonomi, F., Nusantara, U., \& Kediri, P. (2015). 
Analisis Prosedur Kebijakan Pemberian Kredit Pada Bank Jatim Cabang Kendiri.

Puspita, P. (n.d.). Upaya-Upaya Penyelesaian Kredit Macet Oleh Lemabaga Perbankan Terhadap Debitu Wanprestasi, 1-17.

Shanjaya, A. R., \& Marlius, D. (2017). Peranan Laporan Keuangan Dalam Kebijaksanaan Pemberian Kredit Kepada Calon Nasabah Pada PT. BPR Batang Kapas. https://doi.org/10.31227/osf.io/uxmg6

Suarni, K. S., \& Dkk. (2014). Pengaruh Tingkat Suku Bunga Kredit, Tingkat Efisiensi Bank dan Tingkat Kecukupan Modal Terhadap Jumlah Kredit Yang Disalurkan Pada PT Bank Perkreditan Rakyat Nur Abadi Tahun 2011-2013. EJurnal Bisma Universitas Pendidikan Ganesha Jurusan Manajemen, 2(2), 1-9.

Wahyu, T. A. (2017). Sistem Pendukung Keputusan Pemberian Kredit Usaha Kecil Menengah Pada BPR Prima Kredit Mandiri Dengan Menggunakan Metode Logika Fuzzy MADM Dan Fuzzy Sugeno, O(September), 1-15. https://doi.org/10.1017/CBO9781107415324.004

Widayati, R. (2019). Pelaksanaan Prinsip Kehati-Hatian Dalam Pemberian Kredit Konsumtif Pada Bank Nagari Cabang Siteba. https://doi.org/10.17605/OSF.IO/FZVXR

Widayati, R. (2019). Aktivitas Pemberian Kredit Komersil Pada Bank Nagari Cabang Sijunjung. https://doi.org/10.17605/OSF.IO/QTVZ9

Widayati, R. (2019). Pelaksanaan Kredit Pada Bank Perkreditan Rakyat LPN Pasar Baru Durian Sawahlunto. https://doi.org/10.17605/OSF.IO/5HPAB 